\title{
Child, reproductive, mental health; infections and NCDs in the African environment
}

\section{DOI: http://dx.doi.org/10.4314/ahs.v16i4.1}

James K Tumwine

Cite as: Tumwine JK. Child, reproductive, mental health; infections and NCDs in the African environment. Afri Health Sci 2016;16(4): i-iii. DOI: http:/ / dx.doi.org/10.4314/ahs.v16i4.1

Welcome to this December issue of AHS.

In this issue we focus on several themes: child, reproductive and mental health; infections and non communicable diseases.

Child health: The first 10 articles focus solely on child health.

Researchers from Uganda ${ }^{1}$ report on the context surrounding out-of-hospital deaths and the barriers to accessing timely care for Ugandan children recently discharged from the hospital. Compelling reading!

Still in Uganda, ${ }^{2}$ we have reports of a multi-model community nutrition intervention program; while from neighboring Kenya researchers report on the effect of Mother Support Groups on nutritional status of village children. ${ }^{3}$ It seems there is a resurgence of interest in adolescent health. In line with this, we bring you an interesting systematic review of factors affecting energy intake of adolescent girls highlighting the paucity of information in this area. ${ }^{4}$

Now from child nutrition to videos! Mutanda and others report results of an evaluation of community-made mobile videos for maternal newborn and child health $(\mathrm{MNCH})$ education. They assert that "locally made mobile community videos are effective in improving knowledge, attitudes, practices and use of maternal and child health messages among rural semi-illiterate communities." ${ }^{5}$

South African researchers on the other hand report on aspects of care for children with Down's syndrome: subjective experience, perceptions and attitudes of caregivers; and dynamics surrounding care-giving that may influence holistic interventions. ${ }^{6}$

The rest of the child health articles focus on correlates of autism among primary and secondary children in $\mathrm{Ni}$ geria. ${ }^{7}$; Caries and dental erosion vis-à-vis increased softdrink availability in $\mathrm{Uganda}^{8}$; physical activity, body mass index and blood pressure in primary school pupils attending private schools. ${ }^{9}$; and long-term outcome of Tunisian children with primary ciliary dyskinesia confirmed by transmission electron microscopy. ${ }^{10}$

Reproductive health: In the next 6 papers, authors report on several reproductive health issues such as: utilization of ante-natal and delivery services ${ }^{11}$, geophagia in pregnan$\mathrm{cy}^{12}$, and risk factors for pre-hypertension in Congolese women $^{13}$. We have child marriage and implications for mortality, entitlements and freedoms. ${ }^{14}$; and inhibitory ef- fects of Cyperus rotundus on uterine fibroids. ${ }^{15}$; The section ends with a paper on $\operatorname{Ig} G$ isotypic antibodies to crude Plasmodium falciparum blood-stage antigen associated with placental malaria in Cameroon ${ }^{16}$.

\section{Mental health:}

The next section is on mental health. Hence we have articles on demand for psychiatric services ${ }^{17}$; referral letters to the psychiatrist ${ }^{18}$; suicidal ideation and attempt in post conflict Uganda. ${ }^{19}$; and socio-demographic correlates of treatment response among patients with schizophrenia in Nigeria ${ }^{20}$. We also have an article on aerobic exercise, quality of life, psychological wellbeing and systemic inflammation in Alzheimer's disease ${ }^{21}$. In a randomised controlled trial scientists describe the effects of vasodilator- and esmolol-induced hemodynamic stability on early post-operative cognitive dysfunction in elderly patients ${ }^{22}$; while Tunisian researchers report on opiate withdrawal syndrome in buprenorphine abusers admitted to a rehabilitation center ${ }^{23}$. The section ends with a rhetorical question: Does exercise alleviate depression related systemic inflammation in chronic obstructive pulmonary disease patients? $?^{24}$

\section{Infections:}

Subjects on infections include: sero-prevalence of hepatitis delta antibodies in HIV/ hepatitis B co infected patients ${ }^{25}$; post-transplant withdrawal of lamivudine and fatal hepatitis flares in kidney transplant recipients, under immunosuppression, with inactive hepatitis B infection. ${ }^{26}$ The next paper exlores patient satisfaction with TB care clinical consultations ${ }^{27}$; while Abbas reports on glyceryl trinitrate as a novel inhibitor of quorum sensing in Pseudomonas aeruginosa ${ }^{28}$. From South Africa we have an interesting paper on 'Concurrent use of Antiretroviral and African traditional medicines amongst people living with HIV/AIDS (PLWA) in the eThekwini Metropolitan area of KwaZulu Natal. ${ }^{29}$ Ugandan authors report on factors associated with community-acquired urinary tract infections among adults. ${ }^{30}$

\section{Non communicable diseases (NCDs)}

These conditions are on the rise and we find that our authors continue sending in high quality papers. Hence from Uganda, we have a paper on diagnostic accuracy of fine needle aspiration cytology in patients undergoing thyroidectomy ${ }^{31}$; while Ghanaian researchers report on determinants of isolated systolic hypertension among diabetic 
patients ${ }^{32}$. In a randomized clinical trial, Min-Hua Fan and others, ${ }^{33}$ report the effect of individualized diabetes education for type 2 diabetes mellitus. The rest of the NCD articles are on sonographic assessment of the portal vein diameter in apparently healthy adults ${ }^{34}$; usage of motor third party insurance ${ }^{35}$; and use of llocally manufactured wheelchairs in Tanzani ${ }^{36}$. From Malawi we have a report on anatomical and osteometric study of the femoral sulcus angle in adults ${ }^{37}$ while from South Africa we have a report on retinal nerve fibre layer thickness values and their associations with ocular and systemic parameters. ${ }^{38}$

\section{Conclusion:}

Finally, we know that you will enjoy reading this bumper issue of African Health Sciences. Thank you for your custom and for being a reliable partner.

\section{James K Tumwine}

Editor in Chief,

African Health Sciences

\section{References}

1. English L, Kumbakumba E, Larson CP, Kabakyenga J, Singer J, Kissoon N, Ansermino JM, Wong H,Kiwanuka J, Wiens MO. Pediatric out-of-hospital deaths following hospital discharge: A mixed-methods study. Afri Health Sci. 2016;16(4): 883-891. http://dx.doi.org/10.4314/ahs. v16i4.2

2. Tumwesigye NM, Tushemerirwe FB, Kajjura R, Nabunya V, Naitala RA, Namanda C. Nutritional status, feeding practices and values of other related indicators at onset of a multi-model community nutrition intervention program in Mpigi District, Uganda. Afri Health Sci. 2016;16(4): 892903. http://dx.doi.org/10.4314/ahs.v16i4.3

3. Undlien M, Viervoll H-A, Rostad B. Effect of Mother Support Groups on nutritional status in children under two years of age in Laisamis village, Kenya. Afri Health Sci. 2016;16(4): 904-909. http://dx.doi.org/10.4314/ahs. v16i4.4

4. Jodhun BM, Pem D, Jeewon R. A systematic review of factors affecting energy intake of adolescent girls. Afri Health Sci. 2016;16(4): 910-922. http://dx.doi. org/10.4314/ahs.v16i4.5

5. Mutanda JN, Waiswa P, Namutamba S. Community-Made Mobile Videos as a Mechanism for Maternal Newborn and Child Health Education in Rural Uganda; a Qualitative Evaluation. Afri Health Sci. 2016;16(4): 923928. http://dx.doi.org/10.4314/ahs.v16i4.6

6. Barr MD, Govender P, Rencken G. Raising a child with down syndrome: perspectives from South African urban caregivers. Afri Health Sci. 2016;16(4): 929-935. http://dx. doi.org/10.4314/ahs.v16i4.7

7. Chinawa JM, Manyike PC, Aniwada EC, Chinawa AT, Obu HA, OdetundeOI, Nwokocha ARC, Ibekwe R. Prev- alence and socioeconomic correlates of autism among children attending primary and secondly schools in south east Nigeria. Afri Health Sci. 2016;16(4): 936-942. http:// dx.doi.org/10.4314/ahs.v16i4.8

8. Jordan C, Karen C. Caries and dental erosion: are Soroti children and adolescents at risk from increased softdrink availability in Uganda? Afri Health Sci. 2016;16(4): 943-946. http://dx.doi.org/10.4314/ahs.v16i4.9

9. Sadoh WE, Sadoh AE, Onyiriuka AN. Physical activity, body mass index and blood pressure in primary school pupils attending private schools. Afri Health Sci. 2016;16(4): 947-953. http://dx.doi.org/10.4314/ahs.v16i4.10

10. Samia $H$, Khadija $B$, Agnès $H$, Fatma $K$, Ines $T$, Hafedh J, Faten T. Long-term outcome of Tunisian children with primary ciliary dyskinesia confirmed by transmission electron microscopy. Afri Health Sci. 2016;16(4): 954-961. http://dx.doi.org/10.4314/ahs.v16i4.11

11. Abimbola JM, Makanjuola AT, Ganiyu SA, Babatunde UMM, Adekunle DK, Olatayo AA. Pattern of utilization of ante-natal and delivery services in Afon community, north-central Nigeria. Afri Health Sci. 2016;16(4): 962-971. http://dx.doi.org/10.4314/ahs.v16i4.12

12. Macheka LR, Olowoyo JO, Matsela L, Khine AA. Prevalence of geophagia and its contributing factors among pregnant women at Dr. George Mukhari Academic Hospital, Pretoria, South Africa. Afri Health Sci. 2016;16(4): 972-978. http://dx.doi.org/10.4314/ahs.v16i4.13

13. Muchanga MJS, Lepira FB, Tozin R, Mbelambela EP, Ngatu NR, Sumaili EK, Makulo JR, Suganuma N. Prevalence and risk factors of pre-hypertension in Congolese pre and post-menopausal women. Afri Health Sci. 2016;16(4): 979-985. http://dx.doi.org/10.4314/ahs. v16i4.14

14. Adedokun O, Adeyemi O, Dauda C. Child marriage and maternal health risks among young mothers in Gombi, Adamawa State, Nigeria: implications for mortality, entitlements and freedoms. Afri Health Sci. 2016;16(4): 986999. http://dx.doi.org/10.4314/ahs.v16i4.15

15. Ying Ju, Xiao B. Chemical constituents of Cyperus rotundus. L. and the inhibitory effects of its chemical constituent on uterine fibroids. Afri Health Sci. 2016;16(4): 1000-1006. http://dx.doi.org/10.4314/ahs.v16i4.16

16. Anchang-Kimbi JK, Achidi EA, Nkegoum B, Mendimi J-MN, Sverremark-Ekström E, Troye-Blomberg M. IgG isotypic antibodies to crude Plasmodium falciparum blood-stage antigen associated with placental malaria infection in parturient Cameroonian women. Afri Health Sci. 2016;16(4): 1007-1017. http://dx.doi.org/10.4314/ahs. v16i4.17

17. Oluyomi E. Price elasticity of demand for psychiatric consultation in a Nigerian psychiatric service. Afri Health Sci. 2016;16(4): 1018-1022. http://dx.doi.org/10.4314/ ahs.v16i4.18

18. Oluyomi E, Oluremi O. Referral letters to the psychi- 
atrist in Nigeria: Is communication adequate? Afri Health Sci. 2016;16(4): 1023-1026. http://dx.doi.org/10.4314/ ahs.v16i4.19

19. Mugisha J, Muyinda H, Kagee A, Wandiembe P, Mpugu SK, Vancampfort D, Kinyanda E. Prevalence of suicidal ideation and attempt: associations with psychiatric disorders in post conflict Northern Uganda. Afri Health Sci. 2016;16(4): 1027-1035. http://dx.doi.org/10.4314/ ahs.v16i4.20

20. Ezeme MS, Uwakwe R, Ndukuba AC, Igwe MN, Odinka PC, Amadi K, Obayi NO. Sociodemographic correlates of treatment response among patients with schizophrenia in a tertiary hospital in south-east Nigeria. Afri Health Sci. 2016;16(4): 1036-1044. http://dx.doi.org/10.4314/ahs. v16i4.21

21. Abd El-Kader SM, Al-Jiffri OH. Aerobic exercise improves quality of life, psychological wellbeing and systemic inflammation in subjects with Alzheimer's disease. Afri Health Sci. 2016;16(4): 1045-1055. http://dx.doi. org/10.4314/ahs.v16i4.22

22. Sun S-H, Yang L, Sun D-F, Wu Y, Han J, Liu R-C, Wang L-J. Effects of vasodilator- and esmolol-induced hemodynamic stability on early postoperative cognitive dysfunction in elderly patients: a randomized trial. Afri Health Sci. 2016;16(4): 1056-1066. http://dx.doi.org/10.4314/ ahs.v16i4.23

23. Derbel I, Ghorbel A, Akrout FM, Zahaf A. Opiate withdrawal syndrome in buprenorphine abusers admitted to a rehabilitation center in Tunisia. Afri Health Sci. 2016;16(4): 1067-1077. http://dx.doi.org/10.4314/ahs. v16i4.24

24. Abd El-Kader SM, Al-Jiffri OH. Exercise alleviates depression related systemic inflammation in chronic obstructive pulmonary disease patients. Afri Health Sci. 2016;16(4): 1078-1088. http://dx.doi.org/10.4314/ahs. v16i4.25

25. Katwesigye E, Seremba E, Semitala F, Ocama P. Low Sero-prevalence of hepatitis delta antibodies in HIV/ hepatitis B co-infected patients attending an urban HIV clinic in Uganda. Afri Health Sci. 2016;16(4): 1089-1093. http://dx.doi.org/10.4314/ahs.v16i4.26

26. Miao B, Lao X-M, Lin G-L. Post-transplant withdrawal of lamivudine results in fatal hepatitis flares in kidney transplant recipients, under immunosuppression, with inactive hepatitis B infection. Afri Health Sci. 2016;16(4): 1094-1100. http://dx.doi.org/10.4314/ahs.v16i4.27

27. Ssengooba W, Kirenga B, Muwonge C, Kyaligonza S, Kasozi S, Mugabe F, Boeree M, Joloba M, Okwera A, PanACEA. Patient satisfaction with TB care clinical consultations in Kampala: a cross sectional study. Afri Health Sci. 2016;16(4): 1101-1108. http://dx.doi.org/10.4314/ ahs.v16i4.28

28. Abbas HA, Shaldam MA. Glyceryl trinitrate is a novel inhibitor of quorum sensing in Pseudomonas aeruginosa. Afri Health Sci. 2016;16(4): 1109-1117. http://dx.doi. org/10.4314/ahs.v16i4.29

29. Mncengeli S, Panjasaram N, Manimbulu N. Concurrent use of Antiretroviral and African traditional medicines amongst people living with HIV/AIDS (PLWA) in the eThekwini Metropolitan area of KwaZulu Natal. Afri Health Sci. 2016;16(4): 1118-1130. http://dx.doi. org/10.4314/ahs.v16i4.30

30. Kabugo D, Kizito S, Ashok DD, Graham AK, Nabimba R, Namunana S, Kabaka MR, Achan B, Najjuka FC. Factors associated with community-acquired urinary tract infections among adults attending assessment centre Mulago hospital Uganda. Afri Health Sci. 2016;16(4): 11311142. http://dx.doi.org/10.4314/ahs.v16i4.31

31. Masereka R, Okeny PK, Fualal JO, Wamala D. Diagnostic accuracy of fine needle aspiration cytology in patients undergoing thyroidectomy in Uganda: a tertiary hospital experience. Afri Health Sci. 2016;16(4): 1143-1150. http://dx.doi.org/10.4314/ahs.v16i4.32

32. Ephraim RKD, Saasi A-R, Anto EO, Adoba P. Determinants of isolated systolic hypertension among diabetic patients visiting the diabetic clinic at the Tamale Teaching Hospital, Northern Ghana. Afri Health Sci. 2016;16(4): 1151-1156. http://dx.doi.org/10.4314/ahs.v16i4.33

33. Fan M-H, Huang B-T, Tang Y-C, Han X-H, Dong W-W, WangL-X. Effect of individualized diabetes education for type 2 diabetes mellitus: a single-center randomized clinical trial. Afri Health Sci. 2016;16(4): 11571162. http://dx.doi.org/10.4314/ahs.v16i4.34

34. Geofery L, Sani M, Zira JD, Ivor NC, Garba SH. Sonographic assessment of the portal vein diameter in apparently healthy adults in a northern Nigerian population. Afri Health Sci. 2016;16(4): 1163-1168. http://dx.doi. org/10.4314/ahs.v16i4.35

35. Kitunzi H, Mirembe H, Guma C. Influence of awareness on the usage of motor third party insurance. Afri Health Sci. 2016;16(4): 1169-1173. http://dx.doi. org/10.4314/ahs.v16i4.36

36. Amosun SL, Ndosi A, Buchanan H. Locally manufactured wheelchairs in Tanzania -are users satisfied? Afri Health Sci. 2016;16(4): 1174-1181. http://dx.doi. org/10.4314/ahs.v16i4.37

37. Mwakikunga A, Katundu K, Msamati B, GbengaAdefolaju A, Schepartz L. An anatomical and osteometric study of the femoral sulcus angle in adult Malawians. Afri Health Sci. 2016;16(4): 1182-1187. http://dx.doi. org/10.4314/ahs.v16i4.38

38. Mashige KP, Oduntan OA. Retinal nerve fibre layer thickness values and their associations with ocular and systemic parameters in Black South Africans. Afri Health Sci. 2016;16(4): 1188-1194. http://dx.doi.org/10.4314/ ahs.v16i4.39 